\title{
Hepatotoxic Effects of Lead Acetate in Rats: Histopathological and Cytotoxic Studies
}

Haouas Z*, Sallem A, Zidi I, Hichri H, Mzali I and Mehdi M

Laboratory of Histology Embryology and Cytogenetic (UR 12 ES 10), Faculty of Medicine, Street Avicenna, Monastir 5019, University of Monastir, Tunisia

*Corresponding author: Zohra Haouas, Laboratory of Histology Embryology and Cytogenetic (UR 12 ES 10), Faculty of Medicine, Street Avicenna, Monastir 5019, University of Monastir, Tunisia, Tel: 21673 462200; E-mail: zohrahaouas@yahoo.fr

Rec date: May 07, 2014, Acc date: June 14, 2014, Pub date: June 16, 2014

Copyright: ( 2014 Haouas Z, et al. This is an open-access article distributed under the terms of the Creative Commons Attribution License, which permits unrestricted use, distribution, and reproduction in any medium, provided the original author and source are credited.

\begin{abstract}
Lead toxicity is probably the most common form of heavy metal intoxication. The present study was conducted to assess the histopathological and cytotoxic effects of lead exposure on rat liver.

Adult male Wistar rats were randomly divided in 2 groups. The first was exposed to $2 \mathrm{~g}$ of lead acetate in distilled water during 35 days, while the second served as a control group and was given distilled water. The structural damage in the liver was investigated by histological study and supplemented by biochemical assay of liver enzyme levels. DNA fragmentation in somatic cells was determined using terminal desoxynucleotidyl transferase mediated dUTP nick end-labeling (TUNEL) assay.

The results obtained show increase in liver enzyme levels in treated rats compared to controls. The histological study showed that lead can induce several alterations such as hypertrophy of hepatocytes, portal space and central vein dilatation, vacuolation and lymphocytic infiltration. Tunel assay revealed significant DNA fragmentation in rats exposed to lead.

This study showed that TUNEL assay can be used to determinate DNA fragmentation in somatic cells of rat liver. Moreover, we conclude that lead acetate may be considered as a strong hepatotoxic and genotoxic agent.
\end{abstract}

Keywords: Lead acetate; liver; Histopathology; Hepatotoxicity; Tunel assay; DNA damage

\section{Introduction}

There has been growing concern about the rapidly rising levels of environmental chemicals, especially heavy metals such as lead, one of the earliest metals discovered by the human race. It's used in building materials, lead acid batteries, paints, ceramic glazes and for many other purposes. Its exposure mainly occurs through the respiratory and gastro-intestinal systems.

The absorbed $\mathrm{Pb}$ is conjugated in the liver and passed to the kidney, where a small quantity is excreted in urine and the rest accumulates in various body organs and affects many biological activities at the molecular, cellular and intercellular levels, which may result in morphological alterations that can remain even after $\mathrm{Pb}$ levels have fallen [1-4].

Autopsy studies of $\mathrm{Pb}$-exposed humans indicate that liver tissue is the largest repository (33\%) of $\mathrm{Pb}$ among the soft tissues followed by kidney cortex and medulla [5]. It is for this reason that we decided to investigate the impact of lead toxicity on the liver. Lead is known to cause histological liver damage and possibly disturb the normal biochemical process, resulting in increased liver enzyme levels. Mechanisms of lead-induced liver injury include increased production of reactive oxygen species (ROS), and induced oxidative stress which results in DNA damage [6-12]. DNA alteration may occur either via caspase 3 activation or oxidative stress by generating the release of reactive oxygen species (ROS) such as superoxide radicals, hydrogen peroxide and hydroxyl radicals and lipid peroxydation [13-15].

Many reports are available regarding lead toxicity and its deleterious effects on various species of animals but very few researchers have correlated histopathological lesions to DNA alterations. Therefore we carried out this work.

Our aim was to determine the structural damage in the liver by histological study and biochemical assay of liver enzyme levels, and to correlate these findings to DNA fragmentation in somatic cells using terminal desoxynucleotidyl transferase mediated dUTP nick endlabeling (TUNEL) assay.

\section{Materials and Methods}

\section{Experimental animals}

The present study was conducted using 16 male Wistar rats weighing 170-230 $\mathrm{g}$ and three months of age when the experiment was started. They were bred in 2 cages of 8 rats each in a room with a controlled temperature of $21^{\circ} \mathrm{C}$ and $55 \%$ humidity. Rats were kept on a $12 \mathrm{hr}$ light cycle and had access to commercial food and distilled water.

\section{Chemicals}

Lead-acetate $\left((\mathrm{CH} 3 \mathrm{COO})_{2} \mathrm{~Pb}_{3}{ }_{3} \mathrm{H}_{2} \mathrm{O}\right)$ was dissolved in distilled water. 
Page 2 of 6

\section{Experimental design}

Control rats were given distilled water while treated rats were received distilled water rich in lead acetate $(2 \mathrm{~g} / \mathrm{l})$ during 35 days $(6$ days/7).

\section{Blood and organs collection}

Rats from each group were sacrificed. In order to determine liver enzymes (aspartate aminotransferase (AST) and alanine aminotransferase (ALT), blood samples were put in tubes with heparin, and then centrifuged at $4000 \mathrm{rpm}$ during $15 \mathrm{~min}$ and plasma is stored at $-20^{\circ} \mathrm{C}$ until assay. After animal dissection, liver samples were weighed and immediately fixed in $10 \%$ formalin.

\section{Determination of liver enzymes}

AST and ALT levels were determined automatically using Synchron CXq PRO, auto-analyser at Farhat Hached university hospital in Sousse (biochemistry laboratory). The results were expressed in UI/L (Unity International/L)

\section{Histological examination}

The fixed specimens were processed in a series of graded ethanol solutions. They were then embedded in paraffin. Five micrometerthick paraffin sections were obtained by using rotary microtome and stained by Hematoxylin and Eosin (H\&E) or Masson Trichrome (MT).

The specimens were examined and photographed under light microscope Leica DM750, provided with a camera Leica ICC50.

\section{TUNEL Assay}

DNA fragmentation was detected using the « ApopTag ${ }^{\circledR}$ Apoptosis Detection kit, QBiogene, Paris, France " according to manufacturer instructions. Hepatocytes with fragmented DNA were stained with brown while normal ones were greenish.

The number of TUNEL-positive cells (fragmented) was estimated by counting the hepatic cells in seven regions at random area 10-2mm2 section using ZEN 2011 software [16].

\section{Statistical analysis}

Data were analyzed using the Statistical Package for Social Sciences (version 17; SPSS). Differences among groups were measured using one- way analysis of variance (ANOVA) followed by Duncan test. The results were expressed as means \pm SEM and differences were considered statistically significant at $\mathrm{p} \leq 0.05$.

\section{Results}

\section{Body weight gain (\%)}

In this study no significant change $(P \geq 0.05)$ of the reduction of body weight was observed in the treated group in comparison with the control (Table 1).

\section{Absolute and relative liver weight}

In comparison with controls, a significant decrease $(\mathrm{P} \leq 0.05)$ in the absolute and relative liver weights was observed (Table 1 ).

\section{Effects of lead acetate on liver enzymes}

Our results revealed a significant increase in plasma ALT and AST concentrations in treated groups compared with control (Figures 1 and 2).

\begin{tabular}{|l|l|l|l|}
\hline Parameters & Control & Treated & $p$ \\
\hline Body weight gain(g) & $35.23 \pm 10.54$ & $33.54 \pm 6.78$ & $\mathrm{NS}$ \\
\hline Absolute liver weight(g) & $10.74 \pm 0.60$ & $10.42 \pm 1.20^{*}$ & $<0.05$ \\
\hline Relative liver weight(g) & $4.59 \pm 0.63$ & $4.03 \pm 0.13^{*}$ & $<0.05$ \\
\hline $\begin{array}{l}\text { Values are given as Mean } \pm \text { SEM in each group. * Differs significantly at } \\
\text { P<0.05. NS: not significant }\end{array}$ \\
\hline
\end{tabular}

Table 1: Mean values of body, absolute/relative weights of studied rat livers

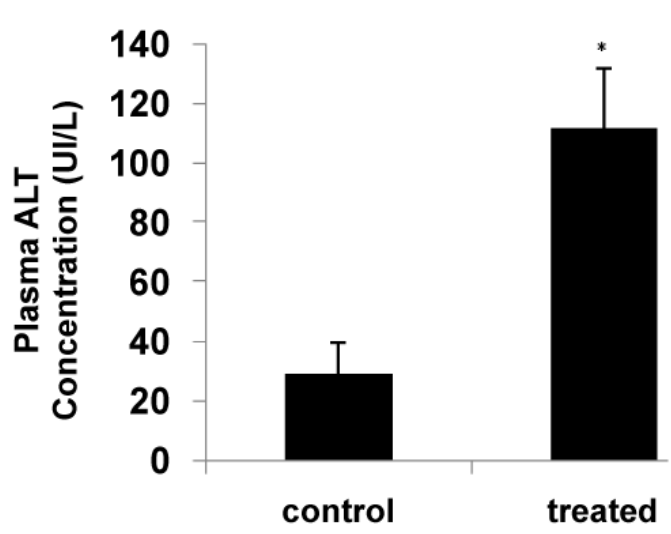

Figure 1: Measure of plasma ALT concentration (UI/L) in rats treated in comparison with control group. The results were expressed in UI/L (Unity International /L). *: Significantly different from the control $(\mathrm{P} \leq 0.05)$

\section{Histological findings}

The liver parenchyma of control rats showed a normal architecture composed of cords that extended from the central vein to the portal space (Figures 3A and 3B) (portal triad). Hepatocytes were arranged in cords separated by capillary sinusoids lined with endothelial cells. Kupffer cells were also present along the sinusoidal capillary. Each hepatocyte is a polygonal cell with a large centrally located spheroid nucleus having a chromatin structure and a distinct nucleolus. The cytoplasm of hepatocytes is faintly granular. In treated rats, liver histopathological examination revealed remarkable degenerative changes such as diffuse disorganization of hepatic cords (Figure 3C), vascular congestion (Figure 3D), dilatation of sinusoids capillary (Figure 3E), central vein and portal space (Figures 3F and 3G). Mild lymphoid (Figure $3 \mathrm{H}$ ) and mononuclear infiltration were observed within the portal areas and central vein the wall of which was dislocated (Figure 3I). Nuclei chromatin was fragmented and cytoplasm contained many vacuoles (Figure 3J). We observed a variation in the size of hepatocytes, some have deeply stained nuclei and homogeneous and acidophil cytoplasm (Figures $3 \mathrm{~K}$ and $3 \mathrm{~L}$ ). 
Hepatocytes proliferation and thickening of liver cell plates without localized distribution among hepatic zones were noted.

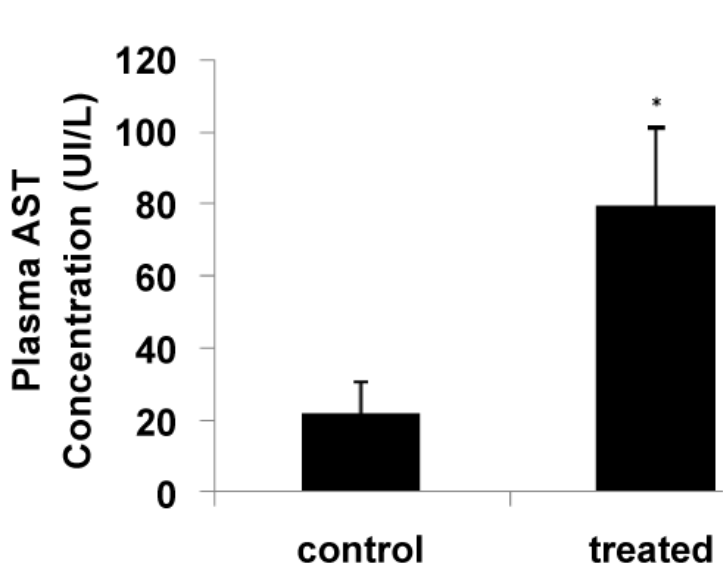

Figure 2: Measure of plasma AST concentration (UI/L) in rats treated in comparison with control group. The results were expressed in UI/L (Unity International /L).

\section{Results of TUNEL Assay}

As expected, few TUNEL-positive cells were observed in the liver of control rats. However, as shown in figure 4, exposure to lead resulted in a more or less significant fragmentation of hepatic cell DNA. The results revealed that the liver of the treated group showed $4.53 \pm 1.23$ fragmented cells $/ \mathrm{mm}^{2}$, whereas in the control group we found only $0.817 \pm 0.704$ fragmented cells $/ \mathrm{mm}^{2}$. Our results showed a significantly increased fragmentation of the DNA in the treated group compared with the control (Figure 5).

\section{Discussion}

In the current study, we observed a reduction of body weight and a significant decrease $(\mathrm{P} \leq 0.05)$ in absolute and relative liver weight in rats exposed to lead acetate. The reduction in body weight in treated rats is possibly attributed to lower food intake from the toxic effects of lead acetate. Decreased body weight was previously observed by Allouche et al. [17] who administered $0.1 \%$ lead acetate to male rats during 11 months.

Moreover, our results are in accordance with other studies showing that exposure of rats to lead acetate causes a decrease in body weight gain [18-21]. The decrease in body weight and absolute liver weight is not only a consequence of decreased food consumption, but also from direct toxicity of the lead acetate, perhaps by malabsorption of nutrients from toxic effects on the gastrointestinal tract or by inhibition of protein synthesis [22,23].

Liver enzymes (AST and ALT) are considered as an important biomarker for the detection of lead hepatotoxicity. According to our results, lead caused a significant increase in AST and ALT levels versus the control group. Increasing levels of AST and ALT in the plasma of treated rats is due mainly to the leakage of these enzymes from the liver cytosol into the blood stream [24]. The AST level rises significantly in the plasma as a consequence of enzyme leakage from the injured hepatic cells into the circulation. ALT also increases in plasma when cellular degeneration or destruction occurs in the organ
[25]. Similar results have been found by Abdel-Kader et al. [26] following administration of $1000 \mathrm{ppm}$ of lead acetate in water to Sprague Dawley rats for 4 weeks. Sivarprasad et al. [27] observed an increase in serum transaminases levels after exposure of male Wistar rats to $0.2 \%$ lead acetate in water for 5 weeks.

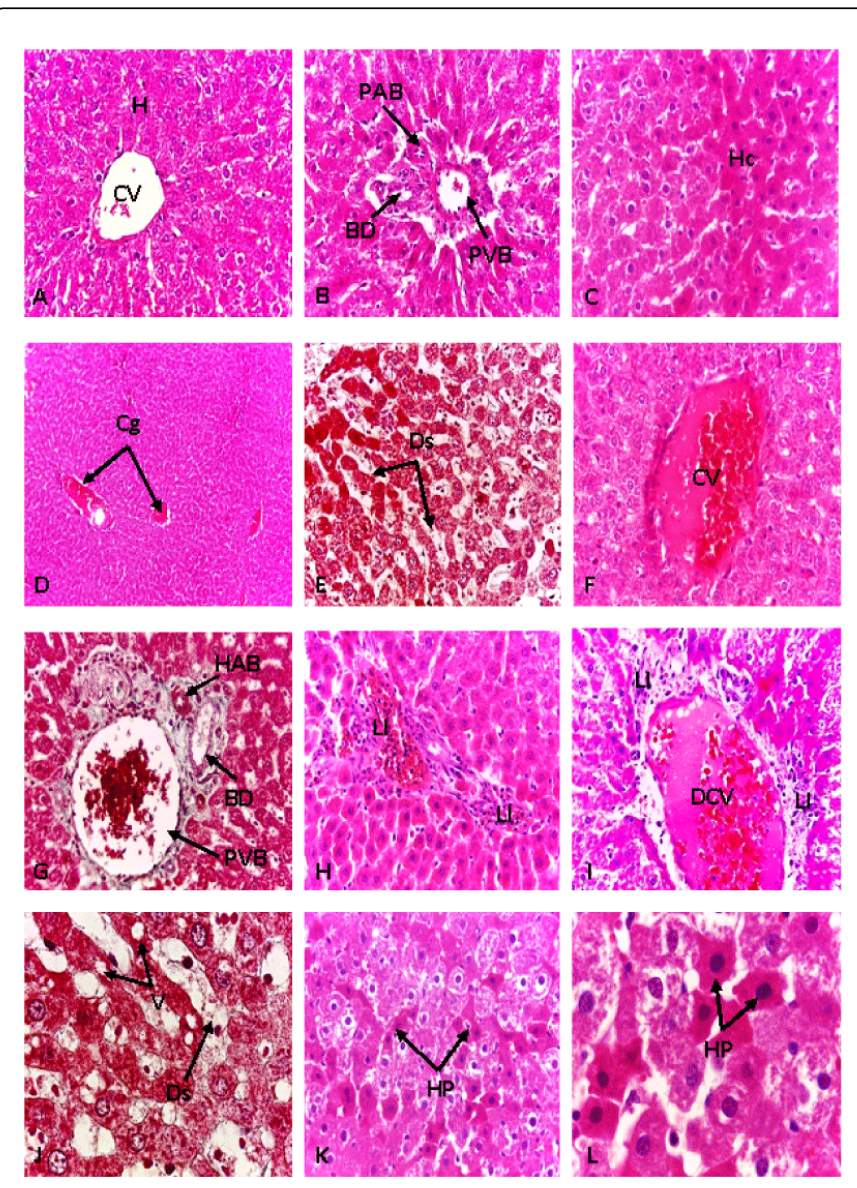

Figure 3: Photomicrographs of rat liver control and treated. The control (A and B, H\&E 400x) reveal normal liver parenchyma with central vein $(\mathrm{CV})$ and portal triad (HAB: hepatic artery branch; PVB: portal vein branch; $\mathrm{BD}$ : bile duct). The rat treated showing change in the liver parenchyma (C, H\&E 400x), vascular congestion (Cg) (D, H\&E 100x), dilatation of sinusoid (Ds) (E, Trichrome 1000x), dilatation of CV (F, H\&E 400x) and hyperthrophy of portal triad (G,Trichrome 400x). In the parenchyma liver lymphoid infiltration (LI) (H, H\&E 400x) and dislocation of CV (DCV) are also seen (I, H\&E 400x). Cytoplasmic vacuolation of some cells (V) with marked dilatation of sinusoid capillaries (J, Trichrome 1000x). The hepatocyte showing loss of their normal architecture (K, 400x; L, 1000x; H\&E). HP: Hepatocyte's proliferation, Hc: hepatic cords. ( $\mathrm{H}$ : hepatocyte; Ds: dilated sinusoids; $\mathrm{CV}$ : centrolobular vein; $\mathrm{Cg}$ : vascular congestion; V: vacuolization; LI: lymphoid infiltration; DCV: dislocation of the wall of the central vein)

We can deduce that high levels of transaminases, normally located in the hepatocyte cytosol, are a sign of cells damage leading to liver dysfunction in treated rats.

The liver is considered as one of the target organs affected by lead toxicity owing to its storage in the liver after lead exposure. Also, the 
Page 4 of 6

liver being one of the major organs involved in the storage, biotransformation and detoxification of toxic substances, is of relevance in heavy metal poisoning [28]. Absorbed lead is stored in soft tissues mainly in the liver [29] via the portal vein, so that it is the first organ for which the histological analysis can be used to examine the morphological changes that reflect possible lead effects on somatic cells [30].
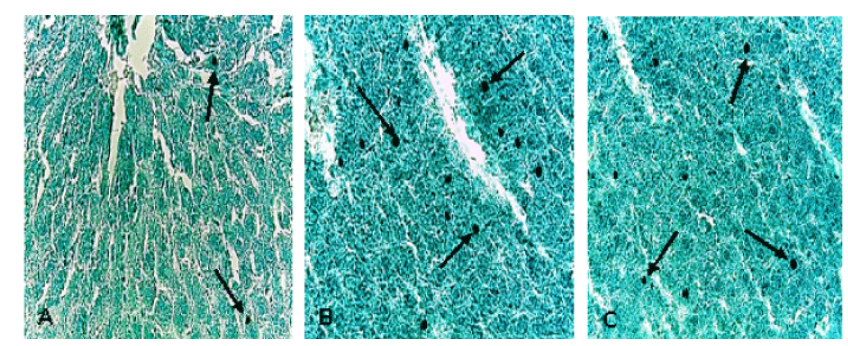

Figure 4: Photomicrographs of TUNEL-stained liver section from control (A) and rats exposed to $2 \mathrm{~g} / \mathrm{l}$ of lead acetate (B and C). Magnification 400x. Arrows indicated TUNEL-positive cells

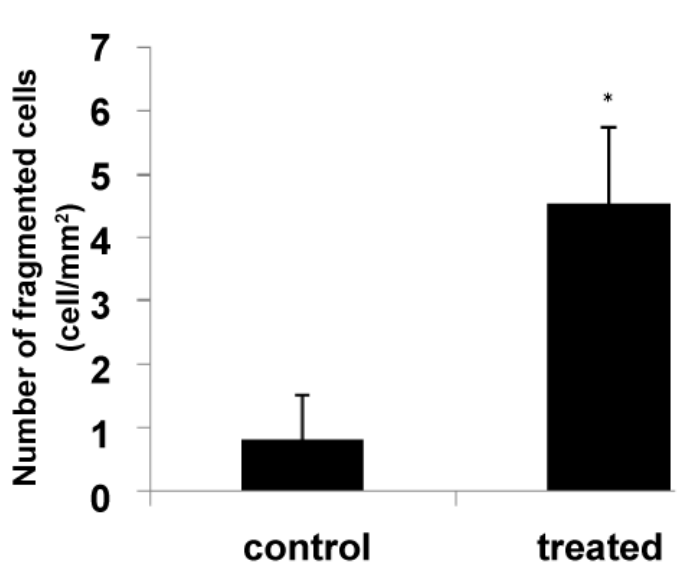

Figure 5: Number of fragmented cells in control and treated rats. *: Significantly different from the control $(\mathrm{P} \leq 0.05)$.

Histological analysis showed several changes such as hepatocytes hypertrophy and disorganization of the hepatic cords. Similar observations were reported by Suradkar [31] in rats receiving 1000 ppm lead acetate for 28 days. The hypertrophy was due to the swelling of intracellular organs especially mitochondria and endoplasmic reticulum [32-35]. Furthermore, hepatic toxicity displays itself in the form of cell vacuolation which is a cellular defense mechanism against injurious substances [36]. These substances were segregated in vacuoles and thus prevented from interfering with cellular metabolism. It has also been suggested that cytoplasmic vacuolation is mainly a consequence of disturbances in lipid inclusions and fat metabolism [37]. Lymphocytic infiltration and sinusoidal blood congestion after treatment with lead are indicators of liver damage. Similar investigations have also been reported by EL-Sokkary et al. [38]; Joher et al. [39]; Liu et al. [16-40]; Sharma et al. [41].
The lymphocytic infiltrates observed in this study following lead treatment show evidence of cell irritability, inflammation and hypersensitivity to the toxicant used. In addition, our results showed portal tact and central vein dilation in accordance with the findings of El-Sokkary et al. [38] who administered $100 \mathrm{mg}$ of lead-acetate to rats. This dilation is probably due to blood congestion.

The TUNEL assay revealed a significant increase in the number of fragmented cells in rats treated with lead. Similar findings were noted by Liu et al. [16] who administered a lower dose of lead $(500 \mathrm{mg} / \mathrm{l})$ during 75 days. Alcaraz-Contreras et al. [42] found that exposure to 3 $\mathrm{g} / \mathrm{l}$ of lead during 5 weeks resulted in hepatocyte DNA fragmentation. Many investigators showed that heavy metals induce DNA fragmentation in liver cells $[43,44]$. One of the mechanisms of DNA fragmentation is apoptosis mediated via Caspase 3 activation which likely trigger autocatalysis as well as cleavage and activation of other caspase family members, leading to rapid and irreversible apoptosis $[45,46]$. Activated caspase- 3 cleaves and activates the $45 \mathrm{kd}$ subunit of DNA fragmentation factor (DFF) which in turn leads to the degradation of DNA into nucleosomal fragments [47], a hallmark of apoptosis [48]. In addition, lead interferes with DNA repair mechanisms that normally take place to preserve DNA integrity, thereby increasing DNA fragmentation further. Several studies showed that DNA damage can be induced by reactive oxygen species (ROS) produced during lipid peroxidation (LPO), [7,16,10] one of the manifestations of oxidative damage which occurs readily in the tissues due to the presence of membrane rich polyunsaturated highly oxidizable fatty acids. It was found that LPO induced by lead alters physiological and biochemical characteristics of biological systems [49]. The improper balance between reactive oxygen species (ROS) metabolites and antioxidant defense results in "oxidative stress". Hydroxyl radicals seem to be the most harmful to cells [50].

\section{Conclusion}

In conclusion, this study showed that TUNEL assay can be used to determinate DNA fragmentation in somatic cells of rat liver. Moreover, these cytogenetic findings were correlated with microscopic study of histological aspect, showing that lead acetate may be considered as a strong hepatotoxic and genotoxic agent. However, further chronic studies are needed to explore mechanisms by which lead acetate led to these toxic effects at the molecular levels.

\section{Acknowledgments}

This work was supported by the funds allocated to the Research Unit of Histology and Genetic UR 12 ES 10 by the "Ministère Tunisien de l'Enseignement Superieur et de la Recherche Scientifique". The authors thank the personnel of the Department of Biochemistry of the University-Hopital Farhat Hached of Sousse (Tunisia) for their help. We also thank the reviewers for their helpful comments.

\section{References}

1. Jarrar BM (2003) Histological and histochemical alterations in the kidney induced by lead. Ann Saudi Med 23: 10-15.

2. Sidhu P, Nehru B (2004) Lead intoxication: histological and oxidative damage in rat cerebrum and cerebellum. J Trace Elem Exp Med 17: 4553.

3. Taib NT, Jarra BM, Mubarek M (2004) Ultrastructural alterations in hepatic tissues of wite rats (Rattus norvegecus) induced by lead experimental toxicity. Saudi J Biol Sci 11: 11-20. 
4. Flora S, Flora G, Saxena G (2006) Environmental occurrence, health effects and management of lead poisoning. In: Casas JS, Sordo J, editors. Lead: chemistry, analytical aspects, environmental impact and health effects. Amsterdam, Netherlands. Elsevier Science.

5. Mudipalli A (2007) Lead hepatotoxicity \& potential health effects. Indian J Med Res 126: 518-527.

6. Guilarte TR (1997) Glutamatergic system and developmental lead neurotoxicity. Neurotoxicology 18: 665-672.

7. Jurczuk M, Brzóska MM, Moniuszko-Jakoniuk J (2007) Hepatic and renal concentrations of vitamins $\mathrm{E}$ and $\mathrm{C}$ in lead- and ethanol-exposed rats. An assessment of their involvement in the mechanisms of peroxidative damage. Food Chem Toxicol 45: 1478-1486.

8. Savolainen KM, Loikkanen J, Eerikäinen S, Naarala J (1998) Interactions of excitatory neurotransmitters and xenobiotics in excitotoxicity and oxidative stress: glutamate and lead. Toxicol Lett 102-103: 363-7.

9. Sieg DJ, Billings RE (1997) Lead/cytokine-mediated oxidative DNA damage in cultured mouse hepatocytes. Toxicol Appl Pharmacol 142: 106-115.

10. Sivaprasad R, Nagaraj M, Varalakshmi P (2004) Combined efficacies of lipoic acid and 2,3-dimercaptosuccinic acid against lead-induced lipid peroxidation in rat liver. J Nutr Biochem 15: 18-23.

11. Xu J, Lian LJ, Wu C, Wang XF, Fu WY, et al. (2008) Lead induces oxidative stress, DNA damage and alteration of p53, Bax and Bcl-2 expressions in mice. Food Chem Toxicol 46: 1488-1494.

12. Zhang J, Wang XF, Lu ZB, Liu NQ, Zhao BL (2004) The effects of meso-2,3-dimercaptosuccinic acid and oligomeric procyanidins on acute lead neurotoxicity in rat hippocampus. Free Radic Biol Med 37: 1037-1050.

13. El-Nekeety AA, El-Kady AA, Soliman MS, Hassan NS, Abdel-Wahhab MA (2009) Protective effect of Aquilegia vulgaris (L.) against lead acetate-induced oxidative stress in rats. Food Chem Toxicol 47: 2209-2215.

14. Hsu PC, Liu MY, Hsu CC, Chen LY, Guo YL (1997) Lead exposure causes generation of reactive oxygen species and functional impairment in rat sperm. Toxicology 122: 133-143.

15. Xu Y, Li G, Han C, Sun L, Zhao R, et al. (2005) Protective effects of Hippophae rhamnoides L. juice on lead-induced neurotoxicity in mice. Biol Pharm Bull 28: 490-494.

16. Liu CM, Ma JQ, Sun YZ (2012) Puerarin protects the rat liver against oxidative stress-mediated DNA damage and apoptosis induced by lead. Exp Toxicol Pathol 64: 575-582.

17. Allouche L, Hamadouche M, Touabti A, Khennouf S (2011) Effect of long-term exposure to low or moderate lead concentrations on growth, lipid profile and liver function in albino rats. Adv Biol Res 5: 339-347.

18. Annabi Berrahal A, Nehdi A, Hajjaji N, Gharbi N, El-Fazâa S (2007) Antioxidant enzymes activities and bilirubin level in adult rat treated with lead. C R Biol 330: 581-588.

19. Ibrahim NM, Eweis EA, El-Beltagi HS, Abdel-Mobdy YE (2012) Effect of lead acetate toxicity on experimental male albino rat. Asian Pac J Trop Biomed 2: 41-46.

20. Shakoor A, Gupta PK, Kataria M, Dwivedi SK (2000) Effect of simultaneous exposure to aluminium and lead on growth in male albino rats. Indian J Toxicol 7: 51-56.

21. Xia D, Yu X, Liao S, Shao Q, Mou H, et al. (2010) Protective effect of Smilax glabra extract against lead-induced oxidative stress in rats. J Ethnopharmacol 130: 414-420.

22. Hammond PB, Minnema DJ, Shulka R (1990) Lead exposure lowers the set point for food consumption and growth in weanling rats. Toxicol Appl Pharmacol 106: 80-87.

23. Minnema DJ, Hammond PB (1994) Effect of lead exposure on patterns of food intake in weanling rats. Neurotoxicol Teratol 16: 623-629.

24. Concepción Navarro M, Pilar Montilla M, Martín A, Jiménez J, Pilar Utrilla M (1993) Free radical scavenger and antihepatotoxic activity of Rosmarinus tomentosus. Planta Med 59: 312-314.
25. Hassoun EA, Stohs SJ (1995) Comparative studies on oxidative stress as a mechanism for the fetotoxic of TCDD, endrin and lindane in C57BL/6J and DBA/2J mice. Teratology 51: 186-192.

26. Abdel-Kader MM, Afify AA, Hegazy AM (2011) Roles of Nacetylcysteine, Methionine, Vitamin $\mathrm{C}$ and Vitamin $\mathrm{E}$ as antioxidants against lead toxicity in rats. Australian J Basic Appl Sci 5: 1178-1183.

27. Sivaprasad R, Nagaraj M, Varalakshmi P (2003) Combined efficacies of lipoic acid and meso-2,3-dimercaptosuccinic acid on lead-induced erythrocyte membrane lipid peroxidation and antioxidant status in rats. Hum Exp Toxicol 22: 183-192.

28. Herman DS, Geraldine M, TV (2009) Influence of minerals on leadinduced alterations in liver function in rats exposed to long-term lead exposure. J Hazard Mater 166: 1410-1414.

29. Patrick L (2006) Lead toxicity, a review of the literature. Part 1: Exposure, evaluation, and treatment. Altern Med Rev 11: 2-22.

30. Abdou HM, Newairy AA (2006) Hepatic and reproductive toxicity of lead in Female rats and attenuation by flaxseed lignans. J M R I 27: 295-302.

31. Suradkar SG, Vihol PD, Patel JH, Ghodasara DJ, Joshi BP, et al. (2010) Patho-morphological changes in tissues of Wistar rats by exposure of Lead acetate. Veter World 3: 82-84.

32. Majno G, Joris I (1995) Apoptosis, oncosis, and necrosis. An overview of cell death. Am J Pathol 146: 3-15.

33. Searle J, Kerr JF, Bishop CJ (1982) Necrosis and apoptosis: distinct modes of cell death with fundamentally different significance. Pathol Annu $17 \mathrm{Pt}$ 2: 229-259.

34. Rosser BG, Gores GJ (1995) Liver cell necrosis: cellular mechanisms and clinical implications. Gastroenterology 108: 252-275.

35. Thompson CB (1995) Apoptosis in the pathogenesis and treatment of disease. Science 267: 1456-1462.

36. Mollendorf A (1973) Cytology Cell Physiology, (3rd edn), Academic Press New York

37. Zhang LY, Wang CX (1984) [Histopathological and histochemical studies on toxic effect of brodifacoum in mouse liver]. Zhongguo Yi Xue Ke Xue Yuan Xue Bao 6: 386-388.

38. El-Sokkary GH, Abdel-Rahman GH, Kamel ES (2005) Melatonin protects against lead-induced hepatic and renal toxicity in male rats. Toxicology 213: 25-33.

39. Johar D, Roth JC, Bay GH, Walker JN, Kroczak TJ, et al. (2004) Inflammatory response, reactive oxygen species, programmed (necroticlike and apoptotic) cell death and cancer. Rocz Akad Med Bialymst 49: 31-39.

40. Liu CM, Ma JQ, Sun YZ (2011) Protective role of puerarin on leadinduced alterations of the hepatic glutathione antioxidant system and hyperlipidemia in rats. Food Chem Toxicol 49: 3119-3127.

41. Sharma A, Sharma V, Kansal L (2010) Amelioration of lead-induced hepatotoxicity by Allium sativum extracts in Swiss albino mice. Libyan J Med 5.

42. Alcaraz-Contreras Y, Garza-Ocañas L, Carcaño-Díaz K, Ramírez-Gómez XS (2011) Effect of glycine on lead mobilization, lead-induced oxidative stress, and hepatic toxicity in rats. J Toxicol 2011: 430539.

43. Ivanov L, Lesauskaité V, Sadauskiene I, Stapilionis R, Ivanoviene L (2002) Acute cadmium exposure changes protein synthesisin mice liver and activates apoptosis. Biomedicine 2: 41-45.

44. Sharma V, Singh P, Pandey AK, Dhawan A (2012) Induction of oxidative stress, DNA damage and apoptosis in mouse liver after sub-acute oral exposure to zinc oxide nanoparticles. Mutat Res 745: 84-91.

45. Srinivasula SM, Fernandes-Alnemri T, Zangrilli J, Robertson N, Armstrong RC, et al. (1996) The Ced-3/interleukin 1beta converting enzyme-like homolog Mch6 and the lamin-cleaving enzyme Mch2alpha are substrates for the apoptotic mediator CPP32. J Biol Chem 271: 27099-27106.

46. Wang X, Zelenski NG, Yang J, Sakai J, Brown MS, et al. (1996) Cleavage of sterol regulatory element binding proteins (SREBPs) by CPP32 during apoptosis. EMBO J 15: 1012-1020. 
Citation: Haouas Z, Sallem A, Zidi I, Hichri H, Mzali I, et al. (2014) Hepatotoxic Effects of Lead Acetate in Rats: Histopathological and Cytotoxic Studies. J Cytol Histol 5: 256. doi:10.4172/2157-7099.1000256

Page 6 of 6

47. Liu X, Zou H, Slaughter C, Wang X (1997) DFF, a heterodimeric protein that functions downstream of caspase-3 to trigger DNA fragmentation during apoptosis. Cell 89: 175-184.

48. Wyllie AH (1980) Glucocorticoid-induced thymocyte apoptosis is associated with endogenous endonuclease activation. Nature 284: 555-556.
49. Patrick L (2006) Lead toxicity part II: the role of free radical damage and the use of antioxidants in the pathology and treatment of lead toxicity. Altern Med Rev 11: 114-127.

50. Wink DA, Laval J (1994) The Fpg protein, a DNA repair enzyme, is inhibited by the biomediator nitric oxide in vitro and in vivo. Carcinogenesis 15: 2125-2129. 